\title{
UPAYA POLRES PASAMAN BARAT DALAM MEMBERANTAS TINDAK PIDANA PERJUDIAN ONLINE
}

\author{
WELLIZAR, HENDRA \\ Sekolah Tinggi Ilmu Hukum Lubuk Sikaping \\ wellizar.ubh@gmail.com
}

\begin{abstract}
The phenomenon of online gambling that is now rife in society, especially in internet cafes or by using a laptop, is lottery gambling. The problems are: 1) What factors encourage online gambling offenders; 2) How are the efforts of the West Pasaman Police in the eradicating of Online Gambling Crime? 3) What are the obstacles faced by the West Pasaman police in eradicating online gambling crime? In conducting the research, the writer uses empirical juridical method which includes secondary data and primary data through interviews and document study. Research location at the West Pasaman Police. The research results are; 1) That the factors driving online gambling offenders are related to the rapid development of advances in telecommunications, media and informatics technology as well as the widespread movement of global information infrastructure; 2) that the efforts made by the West Pasaman Police in Eradicating the Crime of Online Gambling by taking preventive and repressive measures, namely: preventive efforts by collaborating with several ISPs (Internet Service Providers) or internet service providers to close all web sites containing gambling, Providing Appeal through Ads About the Dangers of Gambling, the establishment of the Community Police (Polmas), and conducting Internet Cafes Operations and examinations. Meanwhile, the repressive steps are through enforcement of criminal law. 3) the constraints are: a) Lack of Human Resources; b) Lack of facilities and infrastructure; c) the dualism of legal perceptions, particularly the issue of sanctions, namely the Criminal Code and Article 45 paragraph (1) of Law no. 11 of 2008 concerning Electronic Information and Transactions.
\end{abstract}

Keywords: Effort, Eradicating, Online Gambling.

Abstrak: Fenomena judi online yang marak sekarang ditemui di dalam masyarakat terutamadiwarung-warung internet atau dengan menggunakan laptop adalah judi togel. Permasalahan adalah:1) Faktor apa yang mendorong Tindak Pidana Perjudian Online ? 2) Bagaimana Upaya Polres Pasaman Barat Dalam Memberantas Tindak Pidana Perjudian Online ? 3) Apakah Kendala Yang Dihadapi Polres Pasaman Barat dalam Memberantas Tindak Pidana Perjudian Online ? Dalam melakukan Penelitian penulis menggunakan metode yuridis empiris yang mencakup data sekunder dan data primer melalui wawancara dan studi dokumen. Lokasi penelitian di Polres Pasaman Barat. Hasil penelitian adalah;1) Bahwa Faktor yang mendorong pelaku Tindak Pidana judia Online berkaitan dengan Pesatnya perkembangan kemajuan teknologi telekomunikasi, media, dan informatika serta meluasnya pergerakan infrastruktur informasi global; 2) Bahwa upaya yang dilakukan oleh Polres Pasaman Barat Dalam Memberantas tindak Pidana Perjudian Online dengan melakukan langkah preventif dan represif yaitu : upaya preventif dengan melakukan kerjasama dengan beberapa ISP (Internet Service Provider) atau penyedia jasa internet untuk menutup semua situs-situs yang berpotensi bermuatan konten perjudian, Memberikan Himbauan Melalui Iklan Tentang Bahaya Perjudian, dibentuknya Polmas (Polisi masyarakat), dan Melakukan Operasional dan pemeriksaan Warung Internet. Sedangkan langkah represifnya melalui penegakan terhadap hukum pidana. 3) kendalannya adalah : a) Kurangnya Sumberdaya Manusia; b) Kurangnya sarana dan Prasarana; c) terdapatnya dualisme persepsi hukum, khususnya masalah penetapan sanksi,yaitu KUH dan Pasal 45 ayat (1) UU No. 11 Tahun 2008 Tentang Informasi dan Transaksi Elektronik.

Kata Kunci: Upaya, Pemberantasan, Judi Online. 


\section{A. Pendahuluan}

Perjudian secara tegas dinyatakan didalam Kita Undang-undang Hukum Pidana (KUHP) sebagai kejahatan terhadap kesopanan, sehingga para pelakunya dapat dikenai suatu sanksi pidana. Dalam Kamus Besar Bahasa Indonesia (KBBI), yang dimaksud dengan "judi" adalah "Permainan yang memakai uang/barang berharga sebagai taruhan (seperti main dadu, kartu)". Sedangkan yang dimaksud dengan "berjudi" adalah (Departemen Pendidikan Nasional, 2008): mempertaruhkan sejumlah uang/harta dalam permainan tebakan berdasarkan kebetulan dengan tujuan mendapatkan sejumlah uang atau harta yang lebih besar daripada jumlah uang/harta semula. Bermain dadu (kartu atau sebagainya) dengan taruhan uang/harta. Dalam Undang-Undang Nomor 7 Tahun 1974 Tentang Penertiban Perjudian, tidak ada penjelasan secara detail defenisi dari perjudian, namun dalam Undang-Undang Nomor 1 Tahun 1946 Tentang KUHP, Pasal 303 ayat (3) berbunyi : "Yang dimaksud dengan permainan judi adalah tiap-tiap permainan, dimana kemungkinan untuk menang pada umumnya bergantung pada peruntungan belaka, juga karena pemainnya lebih terlatih atau lebih mahir.

Perjudian merupakan salah satu bentuk kejahatan yang dalam proses sejarah hingga perkembangannya sangat susah diberantas. Dengan demikian, perjudian dapat menjadi penghambat dalam tujuan pembangunan nasional yakni kesejahteraan masyarakat. Oleh karena itu, perjudian harus ditangani dengan cara yang rasional. Maraknya judi di masyarakat jelas akan merusak berbagai sistem sosial masyarakat itu sendiri. Ironisnya, di Indonesia para penjudi ini didominasi oleh kalangan menengah kebawah yang kehidupan ekonominya paspasan (faktabanten, 2021). Mengadu nasib dan peruntungan, sedikit demi sedikit uang didompet habis, kemudian harta benda dijual, rumah dan tanah digadaikan bahkan ada kasus sang anak dan istri pun dijadikan taruhan guna membayar hutang-hutang dari kekalahan judinya.

Seiring dengan perkembangan teknologi dan informasi yang kian pesat, kegiatan berjudi pun mengalami peralihan ke judi online yang lebih praktis dan lebih aman dilakukan. Fenomena judi online yang sekarang marak terjadi adalah judi togel online, yang banyak sekali ditemukan di tengah masyarakat terutama di warung-warung internet, atau dengan menggunakan laptop dalam menjalankan aktivitas tersebut, atau bahkan lewat smartphone yang memiliki fasilitas pendukung atau aplikasi pendukung bermain judi togel online (Asrul Azis, 2012).

Kepolisian sebagai aparat penegak hukum esensinya menegakkan hukum positif dalam penyelenggaraan pemerintahan, yang memiliki tugas pokok sebagaimana yang diatur dalam Pasal 13 Undang-Undang Nomor 2 Tahun 2002 tentang Kepolisian Negara Republik Indonesia. Tugas pokok Polri dalam Pasal 13 tersebut diklasifikasikan menjadi tiga, yakni: memelihara keamanan dan ketertiban masyarakat, menegakkan hukum, dan memberi perlindungan, pengayoman dan pelayanan kepada masyarakat (Sadjijono, 2010).Kabupaten Pasaman Barat merupakan salah satu Daerah yang masih dalam taraf berkembang dari sisi sosial masyarakatnya, yang mana tindak pidana perjudian sering terjadi di daerah tersebut, karena kurangnya kesadaran di daerah tersebut akan bahayanya tindak pidana perjudian, maka dari itu perlunya upaya dari kepolisian resor Pasaman Barat dalam menanggulangi tindak pidana perjudian di wilayah hukum Polres Pasaman Barat.

\section{B. Metodologi Penelitian}

Pendekatan dalam penelitian ini yuridis empiris yang mencakup pada data primer yang langsung didapat dari lapangan, dalam hal ini adalah Polres Pasaman Barat. Upaya dari kepolisian resor Pasaman Barat dalam menanggulangi tindak pidana perjudian di wilayah hukum Polres Pasaman Barat. Berdasarkan uraian diatas, maka dilakukan penelitian lebih lanjut dengan rumusan masalah : 1) Faktor apakah yang mendorong Tindak Pidana Perjudian Online ?; 2) Bagaimana Upaya yang dilakukan oleh Polres Pasaman Barat Dalam Memberantas Tindak Pidana Perjudian Online ? 2) Apakah Kendala Yang Dihadapi Polres Pasaman Barat dalam Memberantas Tindak Pidana Perjudian Online? 


\section{Hasil dan Pembahasan}

\section{Faktor yang mendorong Tindak Pidana Perjudian Online}

Pesatnya perkembangan kemajuan teknologi telekomunikasi, media, dan informatika atau disingkat teknologi telematika serta meluasnya pergerakan infrastruktur informasi global telah merubah juga pola dan cara kegiatan bisnis di bidang industri perdagangan dan pemerintahan. Perkembangan ekonomi berbasis ilmu pengetahuan dan masyarakat informasi telah menjadi paradigma global yang dominan. Kemampuan untuk terlibat secara efektif dalam revolusi jaringan informasi akan menentukan masa depan kesejahteraan bangsa (Budi Agus Riswandi, 2003).

Realita yang ada di wilayah hukum Kepolisian Resor Pasaman Barat saat ini, yaitu maraknya perjudian di lingkungan masyarakat, baik kalangan ekonomi lemah, menengah, maupun atas. Adapun contoh kasus perjudian yang terjadi di wilayah hukum Kepolisian Resor Pasaman Barat dalam perkara atas nama ROKIM Alias ROHIM Bin DASA yang ditangkap karena telah melakukan tindak pidana Perjudian pada hari Rabu tanggal 18Juli 2018 sekitar pukul 21.00, bertempat di warung seberang Rumah Sakit Umum Daerah yang beralamat di Jorong Jambak Selatan Nagari Persiapan Jambak Selatan Kecamatan Luhak Nan Duo Kabupaten Pasaman Barat.

\section{Upaya yang dilakukan oleh Polres Pasaman Barat Dalam Memberantas Tindak Pidana Perjudian Online}

Di wilayah hukum Polres Pasaman Barat, data tindak pidana perjudian online sama sekali tidak ditemui, sementara informasi yang diproleh secara langsung dari pelaku perjudian online, menandakan tindak pidana telah menjadi penyakit masyarakat. Dari data yang didapatkan oleh penulis, melalui wawancara melalui orang yang sedang memainkan perjudian online diwarung internet, di daerah Simpang empat, dapat dilihat bahwa jenis perjudian online yang lebih banyak dimainkan oleh pelaku perjudian online adalah perjudian Togel atau Toto gelap. Alasan pelaku melakukan perjudian online hanyalah untuk iseng semata. Walaupun alasan yang diberikan pelaku hanya iseng-iseng, namun dalam kenyataannya, pelaku melakukan perjudian itu secara terus menerus, karena pelaku mengalami kekalahan, sehingga muncul keinginan untuk menang, dan ingin mencoba lagi.

Upaya yang dilakukan oleh Polres pasaman Barat dalam Memberantas Perjudian online adalah sebagai berikut :

1. Bersifat Preventif. Upaya penanggulangan dengan cara preventif ini tidak memakai sarana pidana, akan tetapi berusaha memanfaatkan potensi-potensi di dalam masyarakat secara terpadu. Langkah awal dalam mencegah perjudian melalui internet adalah sebagai berikut:

a. menutup semua akses ke situs-situs perjudian online. Menurut bapak Ipda Donal, S.H., M.H., selaku Kepala Unit Tipidum Polres Pasaman Barat, melakukan kerjasama dengan beberapa ISP (Internet Service Provider), atau penyedia jasa internet, untuk menutup semua situs-situs yang berpotensi bermuatan konten perjudian, karena semua warung warung internet yang ada di Pasaman Barat pasti menggunakan ISP seperti Speedy, Wanxp, Dashnet dan lain-lain.

b.Memberikan Himbauan Melalui Iklan Tentang Bahaya Perjudian. Langkah tersebut dilakukan dengan memberikan teguran, atau peringatan, melalui iklan media-media sosial yang saat ini sudah banyak digunakan sebagai alat untuk melakukan promosi, pemberitahuan dan lain-lain. Membuat larangan, untuk membuka situs-situs yang memuat konten perjudian dengan mencantumkan kalimat larangan disertai sanksi. Kemudian membuat poster atau selebaran yang ditempel di warung-warung internet dan tempat dimana masyarakat dapat mengakses internet.

c. Dibentuknya Polmas (Polisi masyarakat). Pembentukan Polisi Masyarakat (Polmas) dan Keamanan dan Ketertiban masyarakat (Kantibnas) yang terdapat dimasingmasing kecamatan. System tersebut dilakukan dengan cara mendekatkan diri pada masyarakat, dan harus mengetahui kejadian apa yang terjadi dimasyarakat, dengan 
tujuan selain mendekatkan diri aparat Kepolisian kepada masyarakat, juga bertujuan untuk mencari dan memperoleh informasi dari masyarakat tentang kejahatan yang terjadi di lingkungan yang dimaksud.

d.Melakukan Operasional dan pemeriksaan Warung Internet. Langkah yang terakhir yaitu dengan melakukan razia pada warung internet secara berkala, dan terpusat pada suatu wilayah yang dicurigai saja. selain itu melarang warung internet buka 24 jam karena dapat menimbulkan kejahatan baru pada malam hari.

2. Upaya Represif Melalui Penegakan Hukum. Menurut Soerjono Soekanto, penegakan hukum (law enforcement) menghendaki empat syarat, yaitu : adanya aturan, adanya lembaga yang akan menjalankan peraturan itu, adanya fasilitas untuk mendukung pelaksanaan peraturan itu, adanya kesadaran hukum dari masyarakat yang terkena peraturan itu (Soerjono Soekanto, 1987). Sedangkan menurut Satjipto Rahardjo (1987) pengamatan berlakunya hukum secara lengkap ternyata melibatkan berbagai unsur sebagai berikut: 1) Peraturan sendiri; 2) Warga negara sebagai sasaran pengaturan; 3) Aktivitas birokrasi pelaksana; dan 4) Kerangka sosial-politik-ekonomi-budaya yang ada yang turut menentukan bagaimana setiap unsur dalam hukum tersebut di atas menjalankan apa yang menjadi bagiannya.

Berdasarkan penjelasan tersebut di atas dapatlah ditarik suatu kesimpulan sementara, bahwa masalah pokok dari pada penegakan hukum sebenarnya terletak pada faktorfaktor yang mungkin mempengaruhinya. Faktor-faktor tersebut mempunyai arti yang netral sehingga dampak positif atau negatifnya terletak pada isi dari faktor tersebut. Faktor-faktor yang mempengaruhi law enforcement tersebut adalah: 1) Faktor hukumnya sendiri, yang didalam hal ini mengenai Undang-undang saja; 2) Faktor penegak hukum, yakni pihak-pihak yang membentuk maupun menerapkan hukum; 3) Faktor sarana atau fasilitas yang mendukung penegakan hukum; 4) Faktor masyarakat, yakni lingkungan dimana hukum tersebut berlaku atau diterapkan; 5) Faktor kebudayaan, yakni sebagai hasil karya, cipta dan rasa yang didasarkan pada karsa manusia di dalam pergaulan hidup. Kelima faktor tersebut saling berkaitan antara yang satu dengan yang lainnya karena semuanya merupakan esensi dari penegakan hukum.

Dalam penegakan hukum terhadap tindak pidana perjudian online ini Pihak Kepolisian melakukan upaya penindakan melalui proses peradilan Pidana yang dilaksanakan berdasarkan ketentuan hukum. Hal ini didasarkan pada proses peradilan pidana sebagaimana yang diatur dalam KUHAP. Proses peradilan pidana dimulai dari adanya informasi tentang tindak pidana. AKP. Omri Yan Sahureka, S.H., S.Ik selaku Kepala Satuan Reserse Kriminal Polres Pasaman Barat mengatakan, bahwa dalam penanganan perkara pidana semua laporan polisi yang masuk tentang adanya dugaan tindak pidana memiliki kesamaan dalam penanganannya. Artinya Kepolisian akan menangani semua dugaan tindak pidana yang dilaporkan tanpa adanya perbedaan tertentu dalam penanganannya. Namun demikian, terdapat perkara tertentu yang menjadi skala prioritas diantaranya: a) Pencurian dengan pemberatan; b) Pencurian dengan kekerasan; c) Pencurian Kenderaan bermotor; d) Kejahatan Narkotika; e) Pembunuhan; f) Kekerasan Dalam Rumah Tangga; dan g) Perjudian

Adapun tahapan-tahapan penanganan perkara pidana pada Polres Pasaman Barat adalah sebagai berikut: 1) Adanya laporan polisi yang diajukan oleh seseorang merupakan dasar proses suatu perkara pidana; 2) Setelah adanya laporan polisi tersebut, maka Pimpinan Kepolisian (Kapolda/Kapolres/Kapolsek) memberikan disposisi terhadap Laporan Polisi tersebut kepada unit yang ditunjuk untuk menindaklanjuti Laporan Polisi tersebut; 3) Langkah selanjutnya adalah dilakukan interogasi awal terhadap pelapor untuk mendapatkan informasi awal tentang peristiwa yang dilaporkan; 4) Dengan didapatkannya informasi awal maka langkah selanjutnya adalah dilakukannya penyelidikan; 5) Selanjutnya dilakukan Gelar perkara untuk menentukan apakah peristiwa yang dilaporkan tersebut merupakan suatu tindak pidana atau tidak; 6) Apabila peristiwa tersebut merupakan tindak pidana, maka dikeluarkan Surat Perintah 
Penyidikan dan Surat Pemberitahuan Dimulainya Penyidikan untuk disampaikan kepada Penuntut Umum; 7) Selanjutnya dilakukan pemanggilan terhadap saksi-saksi dan tersangka; dan 8) Penyitaan dan melakukan tindakan hukum sesuai dengan petunjuk Penuntut Umum sehingga berkas perkara tersebut siap untuk disidangkan di Pengadilan.

\section{Kendala Yang Dihadapi Polres Pasaman Barat dalam Memberantas Tindak Pidana Perjudian Online}

Berbicara tentang kendala dalam suatu hal tertentu berarti kita membahas tentang kelemahan atau kekurangan dari suatu sistim yang sudah dibangun dalam suatu unit kerja. Sebaik apaun sistim yang dibentuk untuk menyelesaikan suatu permasalahan pasti ada kendala dalam pelaksanaannya. Namun demikian kendala tersebut bukanlah berarti mengurangi semangat untuk terus memperbaiki sistim yang ada. Begitu juga dalam penyelesaian permasalahan hukum. Dalam memberantas suatu tindak pidana tidaklah semudah membalikkan telapak tangan. Akp Omri Yan Sahureka menambahkan bahwa setiap pelaku tindak pidana akan terus berupaya mencari celah agar tidak terjerat dalam proses pidana. Hal ini adalah suatu keniscayaan dalam prakteknya. Untuk memberantas tindak pidana Perjudian Online ini sendiri pihak Kepolisian pada Polres Pasaman Barat juga memiliki beberapa kendala diantaranya adalah sebagai berikut:

1. Kurangnya Sumberdaya Manusia. Kekurangan sumberdaya manusia merupakan suatu hal yang boleh dikatakan klasik di setiap satuan kerja Polres seluruh Indonesia. Hampir dapat dipastikan bahwa di setiap Polres selalu mengeluhkan kurangnya personil guna mempercepat penanganan perkara ataupun pelayanan masyarakat. Sehingga kendala yang seperti ini dipatikan dialami oleh semua Polres-polres, namun demikian tidak mungkin penegakan hukum tidak dilayani meskipun dalam kondisi yang serba terbatas. Penanganan perkara dan pelayanan masyarakat harus tetap ditumakan walau dalam keterbatasan tersebut. Sebagai contoh dalam satuan reskrim hanya memiliki 8 (delapan) orang penyidik yang memeriksa perkara mulai dari pemberkasan sampai dengan pemeriksaan saksi-saksi dan tersangka. Hal ini berlaku untuk masing-masing penyidik. Lebih lanjut Kasat Reskrim Polres Pasaman Barat tersebut mengungkapkan bahwa saat ini setiap Penyidik sudah menangani masing masing 60 sampai 70 perkara yang harus diselesaikan untuk disidangkan ke Pengadilan. Hal ini memaksa Penyidik-penyidik bekerja siang dan malam tanpa kenal lelah demi penangana perkara.

2. Kurangnya sarana dan Prasarana. Sebanding dengan personalia tersebut di atas, kurangnya sarana dan prasarana dalam proses hukum ini tentu menjadi suatu kendala yang berarti bagi personil yang bertugas. Bagaimana mungkin dalam bertugas masingmasing personil menggunakan fasilitas pribadi, padahal pekerjaan tersebut adalah untuk kepentingan Negara.

3. Kendala Dalam Peraturan Perundang-undangan. Penerapan hukum kepada pelaku perjudian online dilihat dari kendala peraturan perundang-undangan, bahwa perundangundangan yang ada mengatur tindak pidana perjudian online atau menggunakan sistem elektronik ialah UU No. 11 Tahun 2008 Tentang Informasi dan Transaksi Elektronik. Namun undang-undang tersebut menimbulkan dualisme persepsi hukum, khususnya masalah penetapan sanksi yang diatur dalam Pasal 45 ayat (1) UU No. 11 Tahun 2008 Tentang Informasi dan Transaksi Elektronik mengatakan "Setiap orang yang memenuhi unsur sebagaimana yang dimaksud dalam Pasal 27 ayat (1), ayat (2), ayat (3), ayat (4) dipidana dengan pidana penjara paling lama 6 (enam) dan/atau denda paling banyak Rp. 1.000.000.000,00 (Satu miliar rupiah), sedangkan dalam pengaturan KUHP Pasal 303 ayat (1) di ancam dengan pidana penjara paling lama sepuluh tahun atau pidana denda paling banyak Rp. 25.000.000,00 (Dua puluh lima juta rupiah). Hal ini jelas mempersulit penegak hukum dalam pemberian hukuman kepada pelaku yang melakukan tindak pidana perjudian secara online.

Selanjutnya alat bukti yang digunakan dalam tindak pidana perjudian yang menggunakan elektronik, Pasal 43 ayat (3) dan ayat (6) Undang-undang ITE, penggeledahan

442 Lembaga Penelitian dan Penerbitan Hasil Penelitian Ensiklopedia $\quad$ E-ISSN: 2657-0300

P-ISSN: 2657-0319 
dan penyitaan harus dilakukan atas izin Ketua Pengadilan Negeri setempat dalam waktu satu kali dua puluh empat jam, hal ini sulit diwujudkan, karena tidak dimungkinkan mendapat surat izin dari Ketua Pengadilan Negeri setempat untuk melakukan hal tersebut dalam waktu yang sesingkat itu. Kasus yang menjadi bahan pembicaraan dan atau pembahasan dikalangan masyarakat menjadikan masyarakat hanya membicarakan tentang rasa keadlian tanpa mempertimbangkan dampak dari hukum yang ditimbulkan perbuatan negatif itu dan menjadikan masyarakat untuk dekat terhadap perilaku pidana. Masyarakat hendaknya didekatkan kepada penyuluhan hukum dan Negara memang betul-betul memberantas kemiskinan untuk menekan bahkan menghapus tindak pidana perjudian yang diakibatkan dari kurangnya pendidikan dan lemahnya ekonomi masyarakat itu sendiri. Oleh karena undangundang tentang penerapan hukum terhadap tindak pidana perjudian online ini melalui Undangundang ITE sulit untuk diterapkan, maka Penyidik melalui Penuntut Umum lebih memilih menerapkan KUHP. Sehingga perkara perjudian online tersebut masih belum bisa diterapkan dengan UU ITE.

\section{Penutup}

Berdasarkan hasil penelitian dan pembahasan tersebut di atas maka dapat disimpulkan sebagai berikut: 1) Bahwa Faktor yang mendorong Tindak Pidana Perjudian Online berkaitan dengan: a) Pesatnya perkembangan kemajuan teknologi telekomunikasi, media, dan informatika atau disingkat teknologi telematika, serta meluasnya pergerakan infrastruktur informasi global telah merubah juga pola dan cara kegiatan bisnis di bidang industri perdagangan dan pemerintahan. Perkembangan ekonomi berbasis ilmu pengetahuan dan masyarakat informasi telah menjadi paradigma global yang dominan; b) Mudahnya mengakses situs-situs perjudia online; c) Lingkunganyangmemberikan kesempatan. 2) Bahwa upaya yang dilakukan oleh Polres Pasaman Barat Dalam Memberantas Tindak Pidana Perjudian Online dengan melakukan langkah preventif dan represif. Upaya preventif yaitu; a) melakukan kerjasama dengan beberapa ISP (Internet Service Provider) atau penyedia jasa internet untuk menutup semua situs-situs yang berpotensi bermuatan konten perjudian; b) Memberikan Himbauan Melalui Iklan Tentang Bahaya Perjudian; c) Dibentuknya Polmas (Polisi masyarakat); dan d) Melakukan Operasional dan pemeriksaan Warung Internet. Sedangkan langkah represifnya melalui penegakan hukum pidana. 3) Adapun Kendala Yang Dihadapi Polres Pasaman Barat dalam Memberantas Tindak Pidana Perjudian Online adalah; a) Kurangnya Sumberdaya Manusia;b) Kurangnya sarana dan Prasarana; c) terdapatnya dualisme hokum yaitu KUHP dan UU ITE sehingga mempersulit penindakan

\section{Daftar Pustaka}

Adami Charzawi, 2005, Tindak Pidana Mengenai Kesopanan, PT Raja Grafindo Persada, Jakarta

Andi Hamzah, 1994, Asas-Asas Hukum Pidana, Edisi Revisi, Jakarta, Rineka.

Asrul Azis, 2012, Perkembangan Hukum Mengenai Pemberantasan Judi Toto Gelap (Togel) dalam Perpektif Kriminologi,"Jurnal Ilmiah, Medan, Fakultas Hukum Universitas Sumatra Utara.

Baharuddin Lopa, 2001, Permasalahan Pembinaan dan Penegakan Hukum, Jakarta, Bulan Bintang.

Barda Nawawi Arief, 2011, Bunga Rampai Kebijakan Hukum Pidana, Jakarta, Kencana.

Budi Agus Riswandi, 2003, Hukum dan internet, Yogyakarta, UII Press.

Chairul Huda, 2005, Dari Tiada Pidana Tanpa Kesalahan menuju Kepada Tiada Pertanggungjawaban Pidana Tanpa Kesalahan, Jakarta, Kencana Prenada Media.

E.Y. Kanter dan S.R. Sianturi, 2002, Asas-Asas Hukum Pidana di Indonesia dan Penerapannya, Jakarta, Storia Grafika.

H.L.A Hart, 2010, Konsep Hukum, Bandung, Nusamedia.

Ishaq, 2008, Dasar-Dasar Ilmu Hukum, Jakarta, Sinar Grafika.

Kartini Kartono, 2003, Patologi Sosial, Jakarta, Rajawali Pers. 
Leden Marpaung, 2009, Proses Penanganan Perkara Pidana, Jakarta, Sinar Grafika. Moeljatno, 1985, Fungsi dan Tujuan Hukum Pidana Indonesia, Bina Aksara, Jakarta.

Moeljatno, 2008, Asas-asas Hukum Pidana, Jakarta, Rineka cipta.

Mohammad Kholid, Kriminalisasi Persiapan Melakukan Tindak Pidana Sebagai Bentuk PenanggulanganKejahatan Sedini Mungkin, Jurnal Mahkamah, Vol XX, No. 1 April 2008.

M.Yahya Harahap, 2009, Pembahasan Permasalahan dan Penerapan KUHAP (Penyidikan dan Penuntutan), Jakarta, Sinar Grafika.

Poerwardamninta, 1986, Kamus Besar Bahasa Indonesia, Edisi Kedua, Jakarta, Balai Pustaka.

P.A.F. Lamintang, 1990, Delik-Delik Khusus Tindak Pidana-Tindak Pidana Melanggar Norma-Norma Kesusilaan dan Norma-Norma Kepatutan, Bandung, CV Mandar Maju.

P.A.F Lamintang, 2011, Dasar-Dasar Hukum Pidana Indonesia, Bandung, PT Citra Aditya Bakti.

Ridwan A. Halim, 1982, Hukum Pidana dan Tanya Jawab. Ghalia Indonesia, Jakarta.

Romli Atmasasmita, 1996, Sistem Peradilan Pidana (Criminal Justice System / Prespektif Eksistensialisme dan Abolisme ), Jakarta, Putrabadin.

R Soesilo, 1995, Kitab Undang-Undang Hukum Pidana Serta Komentar-Komentarnya Lengkap Pasal Demi Pasal, Politeia, Bogor .

Sadjijono, 2010, Memahami Hukum Kepolisian, Yogyakarta, LaksBang Pressindo.

Satjipto Rahardjo, 1987, Permasalahan Hukum Di Indonesia, Bandung, Alumni .

Soerjono Soekanto, 1987, Pendekatan Sosiologi Terhadap Hukum, Jakarta, Bina Aksara .

Teguh Prasetyo, 2011, Hukum Pidana, Jakarta, Rajawali Pers.

Umar Said Sugiarto, 2012, Pengantar Hukum Indonesia, Jakarta, Sinar Grafika.

Wirjono Prodjodikoro, 1986, Tindak-Tindak Pidana Tertentu di Indonesia, Bandung, PT Eresco.

Wirjono Prodjodikoro, 2003, Asas-Asas Hukum Pidana di Indonesia, Bandung, Refika Aditama. 